\title{
Big Data innowacją w logistyce i zarządzaniu tańcuchem dostaw
}

http://dx.doi.org/10.18778/8142-085-3.10

\author{
Magdalena Nowik \\ Katedra Logistyki \\ Wydział Inżynierii Produkcji i Logistyki \\ Politechnika Opolska
}

\section{Wstęp}

Wraz z rozwojem nowych technologii, Internetu oraz postępem globalizacji liczba oraz tempo wytwarzania danych w postaci cyfrowej niezmiernie wzrosły. Według informacji podanych przez firmę IBM, każdego dnia na całym świecie generowanych jest aż 2,5 tryliona bajtów cyfrowych danych różnego rodzaju (Tabakow, Korczak, Franczyk, 2014). Według badań przeprowadzonych przez IDC Digital Universe (sponsorowanych przez EMC) każdego roku ilość danych tworzonych na całym świecie podwaja się, co oznacza, że nigdy wcześniej nie było aż tylu informacji ${ }^{1}$. W obecnej sytuacji niezbędne jest więc wybranie sposobu, który pozwoliłby na wykorzystywanie zbieranych informacji, które stanowią duży potencjał dla podejmowania decyzji wewnątrz firm i zarządzania łańcuchem dostaw. Jedną z takich metod może być zastosowanie koncepcji Big Data. Celem tego artykułu jest ukazanie idei Big Data, wyjaśnienie jej znaczenia oraz wskazanie sposobów i obszarów implementacji w logistyce i zarządzaniu łańcuchem dostaw.

\section{Charakterystyka Big Data}

Wraz ze wzrostem ilości informacji i danych cyfrowych pojawiły się dwa podstawowe problemy. Pierwszy z nich dotyczy przechowywania danych - potrzeba coraz więcej miejsca na pojawiające się informacje. W dużych firmach, np. produkcyjnych, każdego dnia przybywa wiele zapisów na temat przesunięć to-

1 https://poland.emc.com/about/news/press/2011/20110628-01.htm [dostęp 22.04.2017]. 
warów, planowanych wysyłek, niezgodności w dostawach i produkcji, postępie produkcji, wyprodukowanych sztuk itd. Dane te zajmują dużo miejsca (zarówno cyfrowo $\mathrm{w}$ formie zapisów, jak i fizycznie, $\mathrm{w}$ formie sprzętu), przechowywane na starym sprzęcie mogą prowadzić do jego spowolnienia, a tym samym zmniejszenia wydajności pracy osób, które z niego korzystają. W takich sytuacjach przedsiębiorstwa muszą sięgnąć po nowszy, droższy sprzęt komputerowy oraz oprogramowanie lub zainwestować we własne serwery i bazy danych - oba rozwiązania są stosunkowo drogie. Obecnie zauważa się tendencję, szczególnie w dużych firmach, do korzystania $\mathrm{z}$ baz danych $\mathrm{w}$ tak zwanej chmurze, czyli wirtualnych serwerach - takie rozwiązanie jest mniej kosztowne, jednak łączy się z ryzykiem wykradnięcia lub nawet przejęcia danych przez podmioty zewnętrzne, np. konkurencję. Drugi problem związany z przyrostem danych dotyczy niewystarczających mocy obliczeniowych (ograniczona liczba działań, jakie komputer jest w stanie wykonać w określonym czasie) do ich przetwarzania.

Termin Big Data najczęściej definiowany jest jako „gwałtownie zwiększająca się ilość danych, ich zmienność, różnorodność i częstotliwość powstawania" (Szpor, 2014: 50) . Samo słowo „big” oprócz znaczenia „wielki” - w tym przypadku odnoszącego się do rozmiarów zbiorów danych - odwołuje się także do częstotliwości ich tworzenia, różnorodności, zmienności itd. Inna definicja, która przybliża znaczenie tego pojęcia, została sformułowana przez pracowników firmy analitycznej Gartner, brzmi następująco: „Big data są to źródła danych, które mogą być ogólnie opisane jako: dużej objętości, zmienności i różnorodności, które wymagają wydajnych, innowacyjnych form przetwarzania, w celu pogłębienia ich zrozumienia i podejmowania decyzji” (Szpor, 2014: 51). Pomimo różnic występujących w definicjach obie są poprawne i trafne.

Omawiając koncepcję Big Data, należy wyszczególnić cechy, jakimi się charakteryzuje, co pozwoli na lepsze zobrazowanie i zrozumienie zagadnienia. Big Data wskazuje przede wszystkim na objętość danych i tempo ich powstawania - niewiarygodnie szybki przyrost według prognoz firmy IDC poskutkuje tym, że do $2020 \mathrm{r}$. na świecie wygenerowane zostanie aż 40000 eksabajtów danych cyfrowych, co oznacza pięćdziesięciokrotny wzrost w latach 2009-2020 (Gantz, Reinsel, 2012: 3). Wzrost liczby tych danych prezentuje rysunek 1. Jak można zauważyć, w przeciągu ostatnich lat tempo i objętość tworzonych danych zachowują tendencję rosnącą, oznacza to, że należy przygotować się na dalsze powiększanie ilości informacji, które będzie należało gromadzić, systematyzować i poddawać analizom.

Inną istotną cechą jest różnorodność danych. Chodzi tu głównie o ich pochodzenie, ponieważ tworzone są w odmiennych formach zapisu i odczytu - obrazkowe, liczbowe, tekstowe itd., przy pomocy oprogramowania, które także może się różnić. Źródła danych, a zatem także ich różnorodność, podlegają podziałowi na trzy główne obszary (Szpor, 2014: 54-55):

1. Sieci społecznościowe - wszelkiego rodzaju serwisy, z którymi znaczna część użytkowników ma styczność każdego dnia, np. różnego typu blogi, 
serwisy do odtwarzania i zapisywania wideo, maile, mapy, wyszukiwarki internetowe itd.

2. Systemy biznesowe - zapisy generowane w firmach, które są ściśle powiązane z organizacją i dokonywaniem procesów w przedsiębiorstwie. Tego typu dane są odpowiednio gromadzone i zapisywane w sposób usystematyzowany i przeważnie służą do monitorowania, kontrolowania, ulepszania procesów oraz dokonywania prognoz. Przykładami tego typu danych są np. informacje o produktach w magazynie (położenie produktów wraz z ich numerem seryjnym, datą przydatności, szczegółową lokalizacją, historią itp.), dane na temat postępu produkcji, przyjęcia zleceń i ich realizacji itd.

3. Dane tworzone przez urządzenia i maszyny - używane do monitorowania procesów, pozyskiwane ze sprzętu za pomocą m.in. czujników, sensorów, które rejestrują dane w czasie rzeczywistym; można do tego zaliczyć np. system RFID, który przy pomocy technologii radiowej zapisuje i odczytuje dane dotyczące m.in. lokalizacji produktów, a także kamery czy sensory na drogach, które monitorują natężenie ruchu i dostosowują do niego sygnalizację świetlną (Smart City).

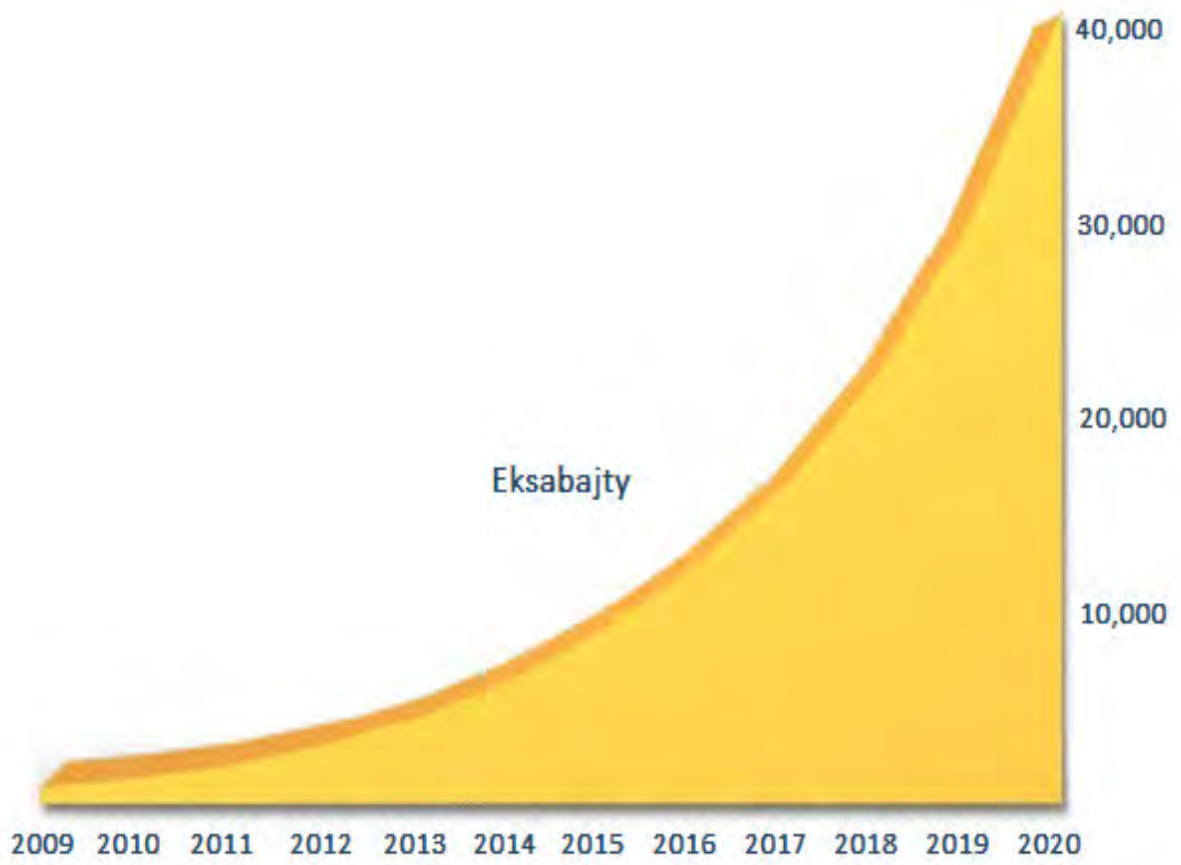

Rysunek 1. Wzrost liczby danych cyfrowych w latach 2009-2020

Źródło: Gantz, Reinsel, 2012: 3. 
Następną cechą „wielkich danych” jest zmienność - podlegają one ciągłej aktualizacji, zapisywane są według określonych schematów i odstępów czasowych. Inna właściwość to złożoność, która ściśle odnosi się do różnorodności - dotyczy to układu danych, ich systematyki - niektóre z gromadzonych zapisów posiadają wspólne właściwości, są do siebie pod pewnymi względami podobne, inne natomiast powierzchownie nie podlegają dopasowaniu do pozostałych posiadanych danych - $\mathrm{w}$ takim przypadku nadrzędnym celem jest znalezienie podobieństw, zależności, w taki sposób, by ich połączenie stanowiło pewną całość, na podstawie której można wnioskować, dokonywać analiz. Dane te niosą ze sobą ogromną wartość, ponieważ powiązania między nimi, odpowiednio zestawione i przeanalizowane, mogą dać odpowiedzi firmom i innym jednostkom na temat np. preferencji klientów, możliwości poprawy procesów, przyczyn problemów pojawiających się w procesach przedsiębiorstw itp.

Analiza Big Data pozwala na poprawienie wydajności przedsiębiorstwa, wzrost efektywności procesów zachodzących w jego wnętrzu, określenie strategii działania oraz przyczynia się do trafniejszego zarządzania firmami, procesami. Badanie i interpretowanie danych może pomóc w podejmowaniu decyzji związanych $\mathrm{z}$ aspektami dotyczącymi np. marketingu - a zatem z całą działalnością firmy. Wyróżnić można tu: „definiowanie obecnych i nowych grup docelowych (segmentacja rynku), tworzenie charakterystyki klienta (rynek i konsumenci), poznanie potrzeb klientów oraz w konsekwencji oferowanie nowych lub bardziej dopasowanych produktów, kreowanie nowych kierunków strategii marketingowej, poprawianie jakości produktu, skracanie i rozszerzanie kanałów dystrybucji, określanie realnej ceny produktu, którą będzie w stanie zapłacić klient, definiowanie kanałów informacyjnych" (Graczyk-Kucharska, 2015).

\section{Zastosowanie koncepcji Big Data w logistyce}

W odniesieniu do logistyki przykładem, który odnosi się do Big Data, jest koncepcja Smart City, polegająca na zastosowaniu wielu technologii w tym samym czasie, takich jak Internet, sieć komórkowa, GPS, GPRS, łącza satelitarne, czujniki ruchu itp. do monitorowania i usprawniania ruchu w mieście. Urządzenia zainstalowane w miastach, takie jak np. radary, kamery, czujniki, sygnalizacja świetlna, inteligentne tablice wyświetlające np. czas odjazdu autobusu, zapisują dane, które aby mogły poprawić warunki komunikacyjne, muszą zostać przeanalizowane i na ich podstawie muszą zostać podjęte decyzje (przez człowieka lub algorytm, który dostosuje np. kolor świateł drogowych). 
Jedną z głównych przyczyn powstania i stosowania Big Data oraz innych innowacji, takich jak np. chmury obliczeniowe (grupa lokalizacji „farm” serwerowych, które świadczą usługi serwerowe), jest postępująca cyfryzacja przemysłu. Proces ten obejmuje zasięgiem cały świat. Polega na zastosowaniu szeroko rozumianych innowacji, technologii i metod do zarządzania i prosperowania przedsiębiorstwa. Odnosi się to do wymiany informacji i danych w czasie rzeczywistym pomiędzy uczestnikami poszczególnych procesów (zarówno pracowników, jak i całych firm), między sobą oraz między urządzeniami. Firmy, aby nie pozostać w tyle za swoimi konkurentami, będą coraz chętniej wykorzystywać najnowsze urządzenia i techniki. W długookresowej prognozie zapewni im to przewagę konkurencyjną bądź utrzymanie pozycji na rynku. Big Data bardzo mocno przenika się z cyfryzacją, ponieważ łączy się ona $\mathrm{w}$ dużym stopniu ze zwiększeniem automatyzacji i gromadzeniem danych, które należy poddać analizie (Pieriegud, 2016).

Firma DHL w 2013 r. opublikowała artykuł poświęcony trendowi Big Data w logistyce. Autorzy wyróżniają w nim pięć głównych aspektów dotyczących logistyki, w których można zastosować Big Data (prezentuje je rysunek 2).

Pierwszy z nich dotyczy optymalizacji ogólnej i głównej działalności przedsiębiorstwa. Szerokie działania i operacje logistyczne, obejmujące wiele rynków czy też podmiotów, potrzebują efektywnego przepływu informacji oraz odpowiedniego ich doboru i zestawienia, który zapewni spełnienie zasady $7 \mathrm{~W}$. Ponadto prognozowanie i analiza przyniosą lepsze wykorzystanie zasobów i pozwolą na osiągnięcie większej wydajności. Oprócz tego umożliwią optymalizację podstawowych zagadnień, jakimi zajmuje się logistyka, czyli wykorzystanie zasobów oraz ich rozlokowanie, skracanie czasu, a także utylizacja odpadów i zwroty.

Drugi obszar logistyki, który koncepcja wielkich danych jest w stanie usprawnić, to dopasowanie świadczeń do klienta i oferowanie mu odpowiedniej jakości usług/produktów. Każdy kontakt z klientem, zarówno bezpośrednie dostarczenie towaru klientowi do domu, jak i spotkanie w punkcie odbioru lub informacja zwrotna przez stronę WWW, to okazja do zebrania danych, które następnie zostaną poddane zestawieniu i analizie. Dzięki temu firmy będą w stanie dopracować wszelkie elementy logistycznej obsługi klienta.

Trzeci obszar wytypowany przez DHL to synchronizacja pomiędzy ogniwami łańcucha dostaw. Logistyka jako element łączący poszczególnie podmioty w łańcuchu ma wpływ na dystrybucję oraz produkcję towarów (pomiędzy ogniwami, jak i do ostatecznych klientów). Wszystkie zbierane dane, po odpowiedniej interpretacji, mogą służyć jako źródła wykrywania zakłóceń, ryzyka i działań niepożądanych w łańcuchu dostaw oraz przyczynić się do ich eliminacji, a także pozwolić na przeciwdziałanie takim zdarzeniom. Oprócz tego Big Data może służyć integracji przedsiębiorstw uczestniczących w łańcuchu dostaw.

Czwarty obszar dotyczy sieci informacji. Dane pobierane mogą być z każdego procesu, na każdym etapie realizacji w odniesieniu do działalności firmy czy całego łańcucha dostaw. Ich analiza może ukazać całe spektrum informacji o przepły- 
wie w skali globalnej. Odpowiednim przykładem jest Holandia, w której prowadzone są statystyki dotyczące ruchu na drogach (jego wielkości oraz dynamiki). Każdego dnia dokonuje się tam około 80 mln zapisów (generowanych aż przez 10 tys. różnego typu rejestratorów). Dzięki temu państwo to dysponuje m.in. informacjami na temat kursów różnego typu pojazdów (zbieranych co minutę), co daje ogromne możliwości do usprawnienia nie tylko całego systemu transportowego kraju, ale również całej jego gospodarki (Szpor, 2014: 58). Przykład ten realnie ukazuje wielkość danych, jakie podlegają pod koncepcję Big Data. Wystarczy, że to państwo zdecydowałoby się na ich szczegółową analizę i zestawienie, a w ręku miałoby bardzo silne narzędzie usprawnienia m.in. systemu transportowego, ale także dostałoby realną szansę na bardzo wnikliwą i precyzyjną prognozę dotyczącą przewidywanych zmian.

Piątym i ostatnim obszarem wyodrębnionym przez DHL jest zasięg oraz obecność na lokalnych rynkach. Zbieranie informacji na wielkim obszarze pozwala na tworzenie analiz ruchu, zagrożeń dla środowiska, jak i dla społeczeństwa. Ponadto umożliwia wdrażanie w przedsiębiorstwach koncepcji zrównoważonego rozwoju, a także poprawianie poszczególnych procesów (Jeske, Grüner, Weiß, 2013: 15).

\section{Przykłady zastosowania Big Data w logistyce}

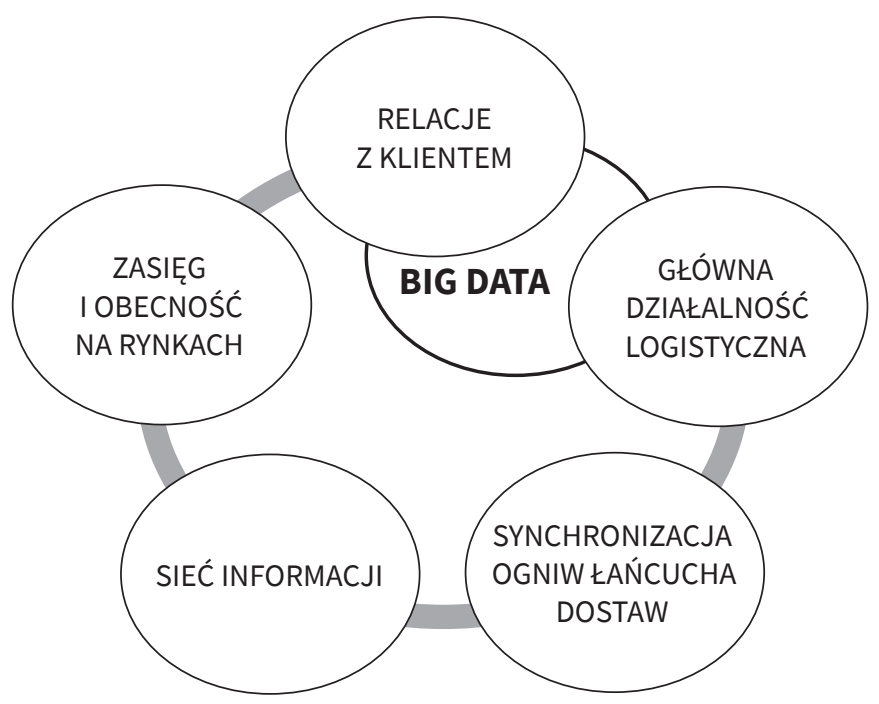

Rysunek 2. Obszary powiązane z logistyką, do których można zastosować Big Data

Źródło: opracowanie własne na podstawie Jeske, Grüner, Weiß, 2013: 15. 
Na rynku globalnym istnieją firmy oraz jednostki, które zastosowały Big Data do przeprowadzenia swoich działań. Poniżej znajduje się opis kilku z nich.

Znana sieć Tesco przez trzy lata prowadziła w Irlandii projekt, który opierał się na zbieraniu danych z lodówek znajdujących się w 120 placówkach, dotyczących czasu pracy oraz temperatur. Poddając analizie te informacje, sieć zaoszczędziła aż 17 mld euro rocznie dzięki jedynie zmniejszeniu temperatur chłodzenia w tych lodówkach o 2 stopnie C (nie zmniejszając przy tym jakości chłodzenia)².

Jeden z europejskich producentów samochodów, wykorzystując dane na temat poszczególnych elementów montowanych w pojazdach, dokonał zmiany w sposobie współpracy ze swoimi dostawcami. Części samochodów zamawiane u dostawców zostały wyposażone w gamę czujników, które wysyłały informacje do producenta w momencie, gdy pojazd był serwisowany. Dane te dotyczyły głównie użycia części podczas jazdy. Ich analizę zlecono zewnętrznej firmie. Przedsięwzięcie miało na celu usprawnić działanie części samochodu, jak i całego pojazdu. Okazało się, że sensor zamontowany w zbiorniku paliwa niemieckiego dostawcy wykazywał, że ten zbiornik nie przynosił zadowalających efektów, ponieważ na dwadzieścia sygnałów wystąpił tylko jeden potwierdzający prawidłowe działanie. Przedsiębiorstwo mogło żądać od dostawcy zwrotu pieniędzy, zadośćuczynienia lub usprawnienia zbiornika, jednak chcąc uzyskać refundację minimum części kosztów, jakie poniesiono na montaż sensorów i analizy, a także unikając wypływu informacji na zewnątrz (konkurencja korzystająca z części tego samego dostawcy mogłaby szybciej zareagować na informację), producent podjął niekonwencjonalne działania i sam ulepszył wadliwą część, zmieniając oprogramowanie. Następnie uzyskał patent na tę metodę poprawy działania zbiorników i odsprzedał ją dostawcy, zyskując na tym nie tylko pieniądze, ale możliwość kontynuacji współpracy z tym dostawcą (Mayer-Schonberger, Cukier, 2014: 175-176).

Kolejnym przykładem zastosowania Big Data są działania operatora metra w Sztokholmie. Testuje on bowiem system oparty na Big Data, który będzie w stanie przewidywać opóźnienia pociągów. Zaprogramowano model, który na podstawie skomplikowanych algorytmów ma tworzyć podgląd metra na około dwie godziny naprzód. Model ma nie tylko przewidywać opóźnienia, ale także pokazywać ich skutki dla całej infrastruktury metra. Logistycy będą mogli lepiej reagować na pojawiające się opóźnienia i próbować je niwelować na czas oraz minimalizować ich ewentualne skutki ${ }^{3}$. System będzie analizował liczne dane na temat aktualnej lokalizacji pociągów, czasu ich postojów, czasu wsiadania pasażerów itd. Może on znacznie usprawnić działanie tego metra, a jeżeli będzie wydajny i efektywny, to prawdopodobnie zainteresują się nim także inne miasta.

2 http://www.focus.pl/technika/8-zastosowan-big-data-o-ktorych-nie-miales-pojecia-12510 [dostęp 23.01.2017].

3 http://it-filolog.pl/big-data-na-lotnisku-i-kolei/ [dostęp 23.04.2017]. 
Ostatnim przykładem zastosowania Big Data jest przypadek producenta silników do samolotów Rolls-Royce’a. Przedsiębiorstwo ciągle analizuje w centrum operacyjnym swoje produkty. Jest to około 3700 silników odrzutowych, które znajdują się w różnych krajach z całego świata. Monitoring polega na tym, że wychwytywane są różnego typu sygnały przed dojściem do uszkodzeń, awarii i błędów. Dzięki temu nie dość że firma zapewnia bezpieczeństwo swoim klientom, to dodatkowo ciągle usprawnia swoje produkty i dąży do uzyskania przez nie perfekcji. Takie podejście i podejmowane działania przyczyniły się do tego, że model firmy uległ całkowitej transformacji - z firmy produkcyjnej, na taką, która świadczy usługi, bowiem obecnie monitoring, wynajem i serwis silników generuje aż 70\% dochodów działu, który obsługuje lotnictwo cywilne (Mayer-Schonberger, Cukier, 2014: 191).

Jak można zauważyć, Big Data stwarza widoczne możliwości zastosowania w branży logistycznej. Pozwala na podniesienie efektywności procesów, skracanie czasów, obniżanie kosztów i strat. Przy tym o ile koncepcja ta może mieć zastosowanie w odniesieniu do logistyki, to odnosząc ją do zarządzania łańcuchami dostaw, staje się nieodłącznym jego elementem, a to z tego względu, że obecnie stawia się coraz bardziej skomplikowane i złożone cele łańcuchom dostaw oraz istnieje przymus wnioskowania $\mathrm{z}$ coraz to większej ilości danych, pochodzących $z$ różnych źródeł o odmiennych cechach. Ponadto obecnie wymaga się coraz bardziej precyzyjnych informacji, a więc trzeba wybierać spośród ogromnych ich ilości, tak aby stanowiły wartość.

Liderzy łańcuchów dostaw z reguły operują znacznie większą ilością informacji niż pozostali jego uczestnicy. W takich przypadkach koncepcja Big Data wydaje się być nieodłącznym elementem ich działania, ponieważ dzięki tym informacjom są w stanie podejmować strategiczne decyzje i tworzyć plany działania, a także pozwala im ona na prognozowanie różnego typu sytuacji, zdarzeń, warunków itd. W takich jednostkach wydzielone także muszą być specjalne działy prognostyczne i analityczne. Big Data pozwoli na bardziej precyzyjne realizowanie wszystkich tych działań.

Firma Lenovo korzystała z Big Data w czasie, gdy na świecie miały miejsce nieprzewidywalne wydarzenia - katastrofy (wybuch wulkanu Eyjafjallajökull na Islandii, trzęsienie Ziemi u wybrzeży Japonii oraz powódź w Tajlandii) oddziałujące także na prosperowanie różnych firm z całego świata, także Lenovo (ze względu na brak możliwości dostarczenia komponentów przez dostawców oraz własne problemy wewnętrzne). Firma ta wbrew trendowi, jaki wówczas panował, czyli spadkowi udziału w rynku - utrzymała swoją pozycję. Ponadto jej udział w rynku wzrósł aż o 6 punktów procentowych. Sytuacja ta wyniknęła dzięki bardzo szybkiemu czasowi reakcji na zdarzenia i szybkiemu podejmowaniu decyzji. Nowe plany zostały bardzo szybko opracowane i wdrożone, co dało firmie przewagę nad konkurencją, niereagującą tak błyskawicznie, a wszystko to za sprawą korzystania z Big Data i bardzo szybkiego opracowywania analiz i scenariuszy przy jej pomocy (Marciniak, Szymczak, 2015). 


\section{Podsumowanie}

W obecnych czasach bardzo istotne jest to, aby informacje nie tylko gromadzić, poddać pobieżnym analizom i przechowywać przez pewien czas, lecz aby wielokrotnie je analizować i zestawiać w różnych konfiguracjach, tak często jak to możliwe i potrzebne. Szczególnie jeśli uwzględni się fakt, że aktualnie tempo przyrostu danych nie zmniejsza się.

Dzięki Big Data dokonywane są nie tylko ewolucje procesów, ich ulepszanie, ale także zmiana modeli przedsiębiorstw, tak jak w opisanym przykładzie Rolls-Royce’a. Koncepcja ta jak najbardziej wpisuje się w logistykę, a przypuszczalnie w przyszłości stanie się także jej nieodłącznym elementem (szczególnie w odniesieniu do zarządzania łańcuchem dostaw).

Należy stwierdzić, że Big Data to realne narzędzie, które może zaspokoić potrzeby wielu jednostek, nie tylko w rozumieniu pojedynczych klientów, ale także całych firm i łańcuchów dostaw (np. potrzeba poznania preferencji klientów, minimalizowania kosztów, zwiększania efektywności procesów).

\section{Bibliografia}

Gantz J., Reinsel D., (2012), IDC View. The Digital Universe in 2020: Big Data, Bigger Digital Shadows, and Biggest Growth in the Far East, December, artykut sponsorowany przez EMC.

Graczyk-Kucharska M., (2015), Big Data koniecznością współczesnego marketingu, „Zeszyty Naukowe Uniwersytetu Szczecińskiego", Problemy zarządzania, finansów i marketingu, nr 41.

Jeske M., Grüner M., Weiß F., (2013), Big Data in Logistics. A DHL perspective on how to move beyond the Hyde, DHL Customer Solutions \& Innovation.

Marciniak M., Szymczak M., (2015), Big data w zarządzaniu tańcuchem dostaw, „Gospodarka Magazynowa i Logistyka", $\mathrm{nr} 7$.

Mayer-Schonberger V., Cukier K., (2014), Big Data. Rewolucja, która zmieni nasze myślenie, pracę i życie, Wydawnictwo MT Biznes, Warszawa.

Pieriegud J., (2016), Cyfrowa transformacja łańcuchów dostaw. Gra o biznes w przyszłości, „EuroLogistics", nr 5.

Szpor G. (red.), (2014), Internet. Publiczne bazy danych i Big Data, Wydawnictwo C.H. Beck, Warszawa.

Tabakow M., Korczak J., Franczyk B., (2014), Big Data - definicje, wyzwania i technologie informatyczne, „Informatyka Ekonomiczna. Bussiness Informatics”, nr 1, Wydawnictwo Uniwersytetu Ekonomicznego we Wrocławiu, Wrocław. 


\section{Źródta internetowe}

http://it-filolog.pl/big-data-na-lotnisku-i-kolei/ [dostęp 23.04.2017].

http://www.focus.pl/technika/8-zastosowan-big-data-o-ktorych-nie-miales-pojecia-12510 [dostęp 23.01.2017].

https://poland.emc.com/about/news/press/2011/20110628-01.htm [dostęp 22.04.2017]. 